\title{
Linking bronchopulmonary dysplasia to adult chronic lung diseases: role of WNT signaling
}

\author{
Chiharu Ota ${ }^{1 *}$, Hoeke A. Baarsma ${ }^{1}$, Darcy E. Wagner ${ }^{1}$, Anne Hilgendorff ${ }^{1,2}$ and Melanie Königshoff ${ }^{1}$
}

\begin{abstract}
Bronchopulmonary dysplasia (BPD) is one of the most common chronic lung diseases in infants caused by preand/or postnatal lung injury. BPD is characterized by arrested alveolarization and vascularization due to extracellular matrix remodeling, inflammation, and impaired growth factor signaling. WNT signaling is a critical pathway for normal lung development, and its altered signaling has been shown to be involved in the onset and progression of incurable chronic lung diseases in adulthood, such as chronic obstructive pulmonary disease (COPD) or idiopathic pulmonary fibrosis (IPF). In this review, we summarize the impact of WNT signaling on different stages of lung development and its potential contribution to developmental lung diseases, especially BPD, and chronic lung diseases in adulthood.
\end{abstract}

Keywords: Bronchopulmonary dysplasia (BPD), WNT signaling, Lung development, Adult chronic lung diseases

\section{Introduction}

Bronchopulmonary dysplasia (BPD) is one of the most common chronic lung diseases in infants. "Old" or "classical" BPD was first defined by Northway et al. in 1967 as structural lung damage and subsequent appearance of parenchymal fibrosis caused by prolonged hyperoxia and ventilator-associated lung injury during the saccular to alveolar stage of lung development [1]. Improvement of clinical neonatal intensive care practices, including prenatal steroid therapy, exogenous surfactant administration, protective lung ventilation strategies, and the careful monitoring of oxygen supplementation, has led to a significant reduction in perinatal respiratoryassociated death. With the current clinical practices, newborns as early as 23 to 26 weeks of gestation are able to survive; however, these newborns present with a distinct form of "new" BPD. The prominent new BPD comprises arrested alveolarization and vascularization, due to the impact of different risk factors on the functionally and structurally immature lung during the early

\footnotetext{
* Correspondence: chiharu.ota@helmholtz-muenchen.de

${ }^{1}$ Comprehensive Pneumology Center, Helmholtz Center Munich, Ludwig-Maximilians-University, University Hospital Grosshadern, German Center of Lung Research (DZL), Munich, Germany

Full list of author information is available at the end of the article
}

canalicular and saccular periods of lung development [2]. Risk factors include hyperoxia-induced oxygen toxicity, mechanical ventilation-induced lung injury, and infection/inflammation of the lungs, which results in aberrant lung development due to extensive remodeling of the extracellular matrix (ECM), perturbations of inflammatory response, and impaired growth factor signaling [3]. Newborns which have survived and developed new BPD are approaching adolescence and adulthood. Several longitudinal studies following patients with new BPD have demonstrated a decline of forced expiratory volume in 1 second (FEV1) compared with term-born controls, reflecting the development of airflow obstruction in new BPD survivors over time [2, 4-6]. These data indicate that impairment of alveolarization/ vascularization during childhood, which is a feature of the new BPD, might contribute to deranged lung alveolar injury/repair processes in adulthood.

Environmental insults, such as smoking, infection, or hyperoxia, are known to cause aberrant alveolar repair processes in deranged lung development and also the adult lung $[7,8]$. These environmental insults contribute not only BPD but also other childhood respiratory diseases including bronchial asthma. A better understanding 
of the processes and signaling pathways altered by these insults are clearly needed.

Impaired signaling of essential lung development pathways, such as fibroblast growth factor (FGF) [9, 10], Wingless/integrase-1 (WNT) signaling [11], or bone morphogenetic proteins (BMPs) [12], have been reported to contribute to the pathogenesis of adult chronic lung diseases, such as chronic obstructive pulmonary disease (COPD) or idiopathic pulmonary fibrosis (IPF) [13]. Of particular interest, WNT signaling has been linked to aberrant alveolar epithelial injury and repair processes [11, 14-17]. Because these pathways are mostly attributed to lung development and are normally thought to be quiescent in the adult lung, this raises the question of why these pathways become aberrant in the adult and whether pre- or postnatal insults impact developmental signal activity early on, thus contributing to an increased susceptibility for chronic lung diseases later in life $[7,18]$. In this review, we focus on the potential role of WNT signaling in lung development and perinatal lung disease, with a focus on BPD, as a disease of impaired alveolarization/vascularization, and discuss the potential link between perinatal and adult chronic lung diseases, such as COPD and IPF.

\section{Review}

\section{Overview of WNT signaling}

WNT signaling is a critical pathway for embryonic development and adult cellular injury and repair processes. There are at least three well-known WNT pathways: canonical ( $\beta$-catenin dependent) signaling and two noncanonical pathways, (i) planar cell polarity (PCP) and (ii) $\mathrm{Ca}^{2+}$-calmodulin-dependent protein kinase II (Camk II)/ protein kinase $C(\mathrm{PKC})$ signaling. As shown in Fig. 1, canonical $\mathrm{WNT} / \beta$-catenin signaling mainly consists of; (i) WNT ligands, (ii) the transmembrane receptors, Frizzled $\left(\mathrm{FZD}_{1-10}\right)$, (iii) the co-receptors low-density lipoprotein

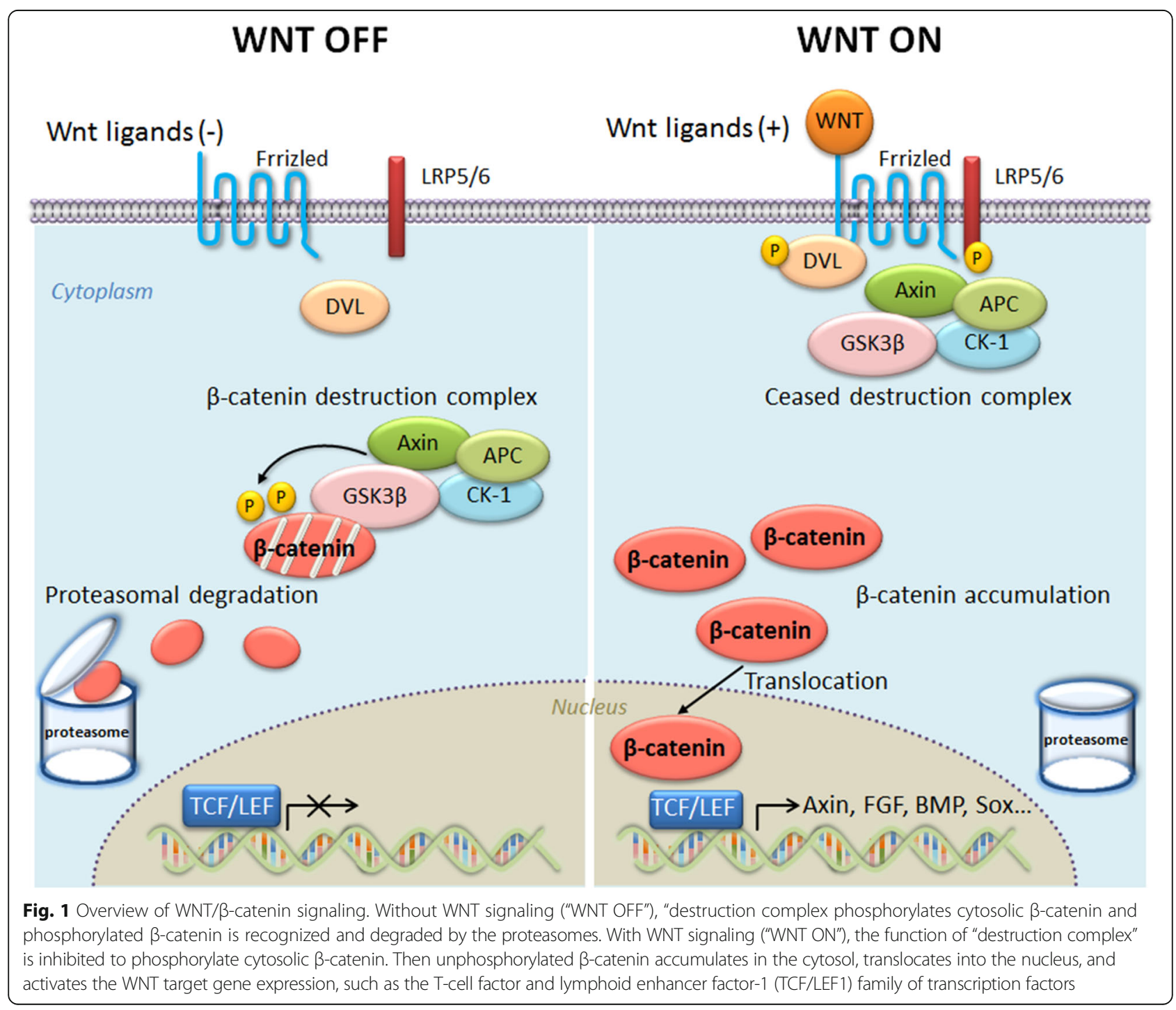


receptor-related proteins (LRP) 5 and 6, (iv) signaling intermediates, Dishevelleds (DVL1-3), (v) the $\beta$-catenin "destruction complex", (vi) the transcriptional coactivator, $\beta$-catenin, and (vii) the transcription factors, $\mathrm{T}$ cell factor and lymphoid enhancer factor (TCF/LEF). Extracellular modulators, such as Dickkopfs (DKK1-4), WNT-inhibitory factor-1 (WIF1), or secreted Frizzledrelated proteins (SFRPs), are also important for regulation of the pathway. In the absence of WNT ligands, $\beta$-catenin is phosphorylated by the destruction complex, which is comprised of Axin, adenomatous polyposis coli (APC), glycogen synthase kinase-3 beta (GSK-3 $\beta$ ), and casein kinase-1 (CK1). Phosphorylated $\beta$-catenin is recognized and ubiquitinated by ubiquitin ligase E3 and subsequently degraded by the proteasome. Upon WNT ligand binding to its receptors, the capacity of the destruction complex to phosphorylate cytosolic $\beta$-catenin is inhibited. Unphosphorylated $\beta$-catenin accumulates in the cytosol, translocates into the nucleus, and activates WNT target gene expression, via its integration with the TCF/LEF family of transcription factors, which is important for cellular proliferation, differentiation, and survival $[11,19,20]$.

Non-canonical WNT signaling (i.e., $\beta$-catenin independent) mainly consists of (i) the WNT/PCP pathway, which activates c-Jun-N-terminal kinase (JNK) and proteins associated with cytoskeleton rearrangement, and (ii) the $\mathrm{WNT} / \mathrm{Ca}^{2+}$ pathway, activating Camk II, PKC, the transcription factor nuclear factor of activated $\mathrm{T}$ cells (NFAT), and several other (less well defined) transcription factors [19]. In this review, we primarily focus on the canonical WNT/ $\beta$-catenin signaling, which has been investigated most extensively so far.

\section{Lung development and WNT signaling}

Historically, a large portion of our knowledge about lung development has been obtained by using wild-type or transgenic mice [21]. In the mouse lung, embryonic lung development starts as early as E9.5 (equivalent to 4 weeks in human gestation), with tightly coordinated epithelial and mesenchymal differentiation processes, and is completed postnatally. At this time point, $N k x 2.1$, a critical homeodomain-containing transcription factor for initial respiratory specification, is expressed within endoderm progenitors in the anterior foregut [21]. Dorsal-ventral specification occurs according to signals, such as BMPs, FGFs, or WNTs, from the surrounding mesenchyme, endoderm, or mesoderm. Primary lung buds generate tree-like structures for branching morphogenesis from E9.5 to E16.5 (in human, 4 to 16 weeks, historically called the "pseudoglandular stage"), followed by the "canalicular stage" (E16.5-17.5 in mouse, 16 to 24 weeks in humans) when terminal sacs are formed, the "saccular stage" (E17.5 to postnatal day 5 in mouse, 24 to 36 weeks in human) when distal airways are developed for the alveoli, and the "alveolar stage" (postnatal day 5 to 30 in mouse, 36 weeks and after delivery in human) when secondary alveolar septa are formed to further divide the airspaces into definitive alveoli (Fig. 2).

WNT signaling is active and highly controlled in a spatio-temporal fashion throughout murine lung endoderm specification in the foregut as well as cellular proliferation and differentiation during lung development [21-24]. In the mouse lung, several loss- or gain-offunction studies revealed the importance of WNT signaling in lung morphogenesis $[25,26]$. Here, we review the role of active WNT signaling during murine lung development (summarized in Table 1).

\section{WNT ligands and their receptors in the developing mouse lung}

A number of WNT ligands and receptors have been identified as being critical for various stages of development. Deletion of the canonical Wnt2 ligand causes mouse lung hypoplasia whereas $W n t 2 / 2 b$ double knockout leads to complete lung agenesis in mice with a loss of $N k \times 2.1$ in early embryonic development in the region where the lung buds are derived from the foregut. Thus $W n t 2$ and $2 b$ are required to specify the $N k x 2.1$ expressed lung progenitors in the foregut through canonical WNT/ $\beta$-catenin signaling $[27,28]$. Similarly, deletion of murine $W n t 7 b$ results in hypoplastic lungs with a proportionate decrease in the replication of both epithelial and mesenchymal progenitors [29]. The noncanonical Wnt4 was reported to be expressed in the anterior trunk mesoderm and was found to be essential for proper lung morphogenesis and trachea formation. In Wnt4 knockout mice, reduced mesodermal proliferation in the lung bud leads to severe lung hypoplasia and tracheal abnormalities [30]. Moreover, Wnt5a, another ligand of non-canonical WNT signaling, has been detected as early as E12 at both epithelial and mesenchymal compartment of the developing lung. The absence of Wnt5a activity is associated with the overbranching of distal airways in murine E15-16 lung together with an architectural immaturity of the capillaries and alveolar airspaces [31]. Vice versa, Wnt5a overexpression in the distal epithelium results in reduced epithelial branching and dilated distal airways [32]. These data highlight that both canonical as well as non-canonical signal aberrations affect normal lung development.

In addition to WNT ligands, the receptors have also been shown to be important for proper lung development. Tissue-specific analysis of the WNT receptors from E12.5 to E16.5 revealed FZD1, 4, and 7 to be primarily expressed in the developing mouse lung mesenchyme and FZD10 in distal airway epithelium and the expression of those receptors decreases after E14.5 [33]. FZD2 is also highly expressed in distal airways [34], and 


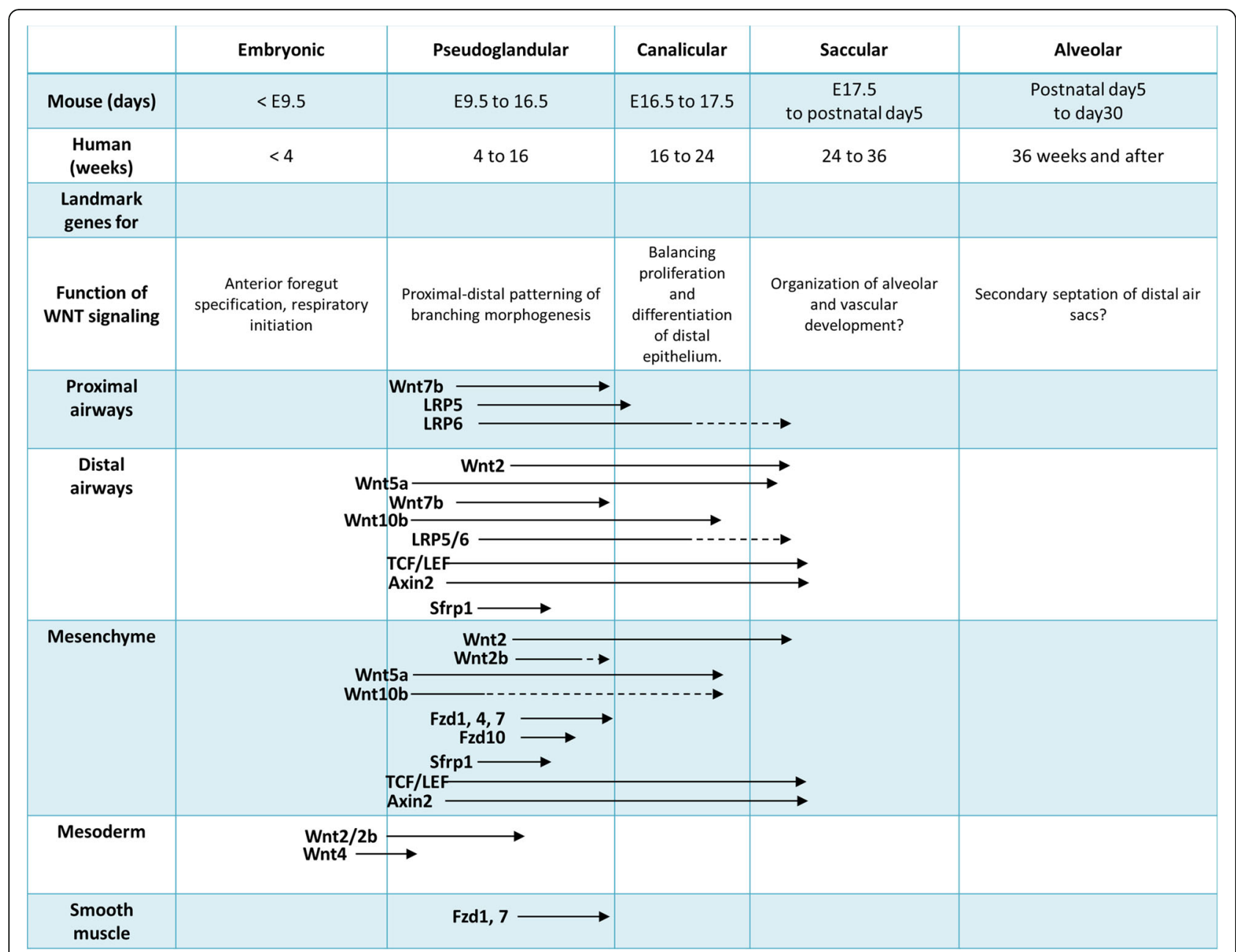

Fig. 2 Developmental stages and the WNT/ß-catenin signaling. In the embryonic stage ( $<E 9.5$ in mouse, $<4$ weeks in human), Wnt2/2b is expressed within surrounding mesenchyme for the anterior foregut specification and the onset of lung specification. In the pseudoglandular stage (E9.5 to 16.5 in mouse, 4 to 16 weeks in human), several Wht ligands, receptors, and extracellular modulators are expressed within proximal or distal airways and surrounding mesenchyme and coordinate proximal-distal patterning of branching morphogenesis. In the canalicular stage (E16.5 to 17.5 in mouse, 16 to 24 weeks in human), WNT/ $\beta$-catenin signaling regulates the balance of proliferation and differentiation of the distal epithelium. In the saccular to alveolar stage (E17.5 to postnatal day 5, postnatal day 5 to day 30 in mouse, 24 weeks to 36 weeks, 36 weeks and after in human), WNT/ß-catenin signaling may organize the alveolarization and vascularization and the formation of secondary septa

epithelium-specific deletion of $F z d 2$ causes formation of cysts in distal airways and defective branching morphogenesis [35]. Furthermore, FZD8 is expressed throughout the pulmonary epithelium [36]. Both LRP5 and LRP6 are expressed in the upper airway epithelium, and LRP5, but not LRP6, is also expressed in the smooth muscle compartment of large vessels [33]. Loss of Lrp5 inhibits angiogenesis and alveolar formation in neonatal mice in the alveolar stage of lung development [37]. While these data further underline the importance of WNT signaling during development, much less is known how these receptors are distinctly involved in canonical versus non-canonical WNT signaling. Furthermore, future studies elucidating cell-specific expression under (patho-) physiologic conditions are needed.

\section{$\beta$-Catenin in normal lung development}

Studies modulating the major effector protein of canonical WNT signaling, $\beta$-catenin, revealed that both epithelial and mesenchymal $\beta$-catenin is required for the onset of lung specification and the proximal-distal patterning of branching morphogenesis: deletion of $\beta$-catenin in the foregut leads to the loss of $N k \times 2.1$ expression and the absence of both the trachea and lung due to a lack of respiratory lineage initiation $[27,38]$. Lung epitheliumspecific deletion of $\beta$-catenin caused disruption of distal but not proximal airways in the later stages of lung development [28]. On the other hand, conditional knockout of $\beta$-catenin in mesenchymal cells resulted in a shortened trachea and reduced branching morphogenesis in E12.5 to E14.5 lungs [23]. In addition to the localization, the timing 
Table 1 Summary of developmental WNT/ß-catenin signaling, expression pattern, study models, and phenotypes

\begin{tabular}{|c|c|c|c|c|}
\hline & Expression & Study model & Phenotype & Reference \\
\hline \multicolumn{5}{|l|}{ WNT ligands } \\
\hline WNT2 & MS & Wnt2 knockout & $\begin{array}{l}\text { 1. Hypoplastic lungs with relatively normal airway development } \\
\text { 2. Reduced proliferation of EP and MS lineage } \\
\text { 3. Several signaling pathways and transcription factors for lung } \\
\text { development were reduced }\end{array}$ & [27] \\
\hline WNT2b & MS & Wnt2b knockout & Viable and no discernable phenotype & [27] \\
\hline WNT2/2b & MS & Wnt2/2b double knockout & Complete lung agencies & [27] \\
\hline WNT4 & MS & Wnt4 knockout & $\begin{array}{l}\text { 1. Lung hypoplasia and tracheal abnormalities } \\
\text { 2. Reduced mesodermal proliferation in the lung bud }\end{array}$ & {$[30]$} \\
\hline WNT5a & $\begin{array}{l}\text { MS, EP(E12) } \\
\text { Distal and proximal EP (E16) } \\
\text { Cells surrounding distal } \\
\text { and proximal EP (E18) }\end{array}$ & $\begin{array}{l}\text { Wnt5a knockout } \\
\text { Wnt5a-SPC transgenic }\end{array}$ & $\begin{array}{l}\text { 1. Larger lungs, foreshortened trachea, overexpansion of distal airways, } \\
\text { thickened intersaccular interstituim (knockout) } \\
\text { 2. Smaller lungs, reduced number of alveolar sacs with dilated alveoli, } \\
\text { lobation abnormalities (transgenic) }\end{array}$ & $\begin{array}{l}{[31]} \\
{[32]}\end{array}$ \\
\hline WNT7b & $\begin{array}{l}\text { EP (E12.5 to E16.5) both in } \\
\text { the distal and larger mainstem } \\
\text { bronchial airways }\end{array}$ & $\begin{array}{l}\text { Conditional knockout of Wnt7b in } \\
\text { Sox2-expressed embryo }\end{array}$ & $\begin{array}{l}\text { 1. Hypoplastic lungs with normal patterning and cell differentiation } \\
\text { 2. Proportionate decrease in the replication of epithelial and } \\
\text { mesenchymal progenitors }\end{array}$ & [29] \\
\hline \multicolumn{5}{|c|}{ WNT receptors } \\
\hline FZDI & MS & In situ hybridization & NA & [33] \\
\hline FZD2 & EP (distal) & $\begin{array}{l}\text { Conditional knockout of Frz2 in } \\
\text { Shh-expressing cells }\end{array}$ & $\begin{array}{l}\text { Formation of cysts in distal airways and defective branching } \\
\text { morphogenesis }\end{array}$ & {$[35,36]$} \\
\hline FZD4 & MS & In situ hybridization & NA & {$[33]$} \\
\hline FZD7 & MS & In situ hybridization & NA & [33] \\
\hline FZD8 & EP & In situ hybridization & & [34] \\
\hline FZD10 & EP (distal) & Immunohistochemistry & NA & [33] \\
\hline LRP5 & $\begin{array}{l}\text { EP (upper airway), muscular } \\
\text { component of large vessels }\end{array}$ & Lrp5 knockout & $\begin{array}{l}\text { Impairment of alveolar and vascular formation in neonatal lungs } \\
\text { due to the decrease of angiopoietin/Tie2 pathway }\end{array}$ & {$[33,37]$} \\
\hline LRP6 & EP (upper airway) & In situ hybridization & NA & {$[33]$} \\
\hline \multicolumn{5}{|c|}{ Extracellular modulators } \\
\hline DKK-1 & EP (distal) & In situ hybridization & $\begin{array}{l}\text { Treatment of E1 } 1.5 \text { lung explants by Dkk1 disrupts branching } \\
\text { morphogenesis }\end{array}$ & [34] \\
\hline SFRP-1 & MS, EP (distal) & Sfrp-1 knockout & $\begin{array}{l}\text { Marked dilation of the alveolar duct with the loss of surrounding } \\
\text { messenchymal component }\end{array}$ & {$[43]$} \\
\hline \multicolumn{5}{|c|}{$\beta$-catenin destruction complex } \\
\hline APC & MS & $\begin{array}{l}\text { Conditional knockout of } A p c \text { in } \\
\text { Tbx4-expressing mesenchymal cells }\end{array}$ & $\begin{array}{l}\text { APC knockout fetus shows severe lung hemorrhage in E14.5 and } \\
\text { dies in E15.5, with condensed mesenchymal cells around } \\
\text { epithelial tubes in the lung. }\end{array}$ & {$[44,45]$} \\
\hline
\end{tabular}
1. Hypoplastic lungs with normal patterning and cell differentiation
2. Proportionate decrease in the replication of epithelial and

NA

Conditional knockout of Frz2 in

ofysts in distal airways and defective branching

In situ hybridization

In situ hybridization

epithelial tubes in the lung. 
Table 1 Summary of developmental WNT/ß-catenin signaling, expression pattern, study models, and phenotypes (Continued)

\begin{tabular}{|c|c|c|c|c|}
\hline \multicolumn{5}{|l|}{$\beta$-catenin } \\
\hline$\beta$-catenin & $E P, M S$ & $\begin{array}{l}\text { 1. Conditional knockout of } \beta \text {-catenin in } \\
\text { SPC-expressing cells } \\
\text { 2. Conditional knockout of } \beta \text {-catenin in } \\
\text { Shh-expressing cells } \\
\text { 3. Conditional knockout of } \beta \text {-catenin in } \\
\text { Sox2-expressing cells } \\
\text { 4. Conditional knockout of } \beta \text {-catenin in } \\
\text { Demol-expressing mesenchymal cells }\end{array}$ & $\begin{array}{l}\text { 1. Multiple, enlarged, and elongated bronchiolar tubes with a lack } \\
\text { of alveolar sacs ( } \beta \text {-catenin-SPC knockout) } \\
\text { 2. Absence of both trachea and lung due to the defect of Nk×2.1 } \\
\text { expression (B-catenin-Shh knockout) } \\
\text { 3. Defective bronchiolar epithelial cell differentiation and marked } \\
\text { ectasis of the developing and adult airway ( } \beta \text {-catenin-Sox2 knockout) } \\
\text { 4. Shortened trachea and reduced branching morphogenesis. } \\
\text { Defect of sub-mesothelial mesenchymal domain containing } \\
\text { Fgf10-expressing progenitors. }\end{array}$ & {$[26,28,38-40]$} \\
\hline
\end{tabular}

MS mesenchymal cells, EP epithelial cells 
and duration of $\beta$-catenin expression are important for proper lung development. Prolonged activation of a $\beta$ catenin-Lef1 fusion protein in distal lung endoderm led to the development of an undifferentiated distal airway epithelium and resulted in ectopic expression of gene characteristic of intestinal epithelial lineages [26]. Another study revealed that sustained $\beta$-catenin activity within the distal lung endoderm in early lung development results in the loss of Sox2, a regulator of developing proximal airway progenitors, and defective bronchiolar epithelial cell differentiation and marked ectasia of the developing and adult airway [39]. $\beta$-Catenin appears to be an essential mediator with critical links to its target transcription factors as well as various signaling pathways associated with lung development, such as, FGF [40], BMP4, or N-myc [41] signaling.

\section{WNT signal antagonists in the developing mouse lung}

Activation of WNT signaling is highly controlled by several intra- and extracellular proteins. Dickkopf (DKK1-4) proteins antagonize $\mathrm{WNT} / \beta$-catenin signaling by binding to LRP5/6. Dkk-1,2, and 3 are expressed in distal lung epithelium from E11.5 (Dkk-2), E12.5 (Dkk-3), and E13.5 (Dkk-1) onward [36]. WNT/ $\beta$-catenin signaling was decreased in distal airways of TOPGAL WNTreporter mouse at E14.5 after the onset of Dkk-1 expression in the distal lung [36]. Furthermore, the DKK-1treated lung explants from E11.5 mice showed impaired branching, failed cleft formation, and enlarged terminal buds with fibronectin deposition [36]. Retinoic acid (RA) is a known canonical WNT activator. Using mice with an RA-deficient lung foregut, it was shown that WNT/ $\beta$-catenin signal activation, at the onset of lung specification, is dependent on the repression of $D k k-1$ by endogenous RA [42], indicating that repression and expression of DKKs takes part in $\mathrm{WNT} / \beta$-catenin signaling coordination during lung development.

SFRP-1, which antagonizes WNT/ $\beta$-catenin signaling by binding extracellular WNT ligands, can also be detected in the distal epithelium and the surrounding mesenchyme from E13.5 to 15.5; however, it has not been observed in the later stages of lung development [43]. In Sfrp-1 knockout mice, it was shown that nuclear $\beta$ catenin levels were enhanced after E16.5 to E18.5 and that the alveolar ducts were dilated postnatally compared with the wild-type mice [43], indicating that SFRP-1 is involved in the coordination of nuclear $\beta$ catenin translocation for proper alveolarization.

$\mathrm{APC}$, a component of the intracellular $\beta$-catenin destruction complex, is highly expressed in mesenchymal cells surrounding the large airways at E14.5 lung and can be detected in both mesenchymal as well as epithelial cells at E18.5 [44]. Lung mesenchyme-specific conditional $A p c$ knockdown results in hyperactivation of $\beta$ - catenin in embryonic lung mesenchyme at E10.5 and fetal death at E15.5 due to massive pulmonary hemorrhage. Histological analysis of Apc knockout mice revealed abnormal proliferation and disrupted differentiation of pulmonary mesenchymal cells and inhibition of branching morphogenesis and vasculogenesis [45].

Taken together, WNT signal components, including several antagonists, are involved in a variety of critical processes during murine lung development, including the onset of lung specification, branching morphogenesis, alveolar formation, and angiogenesis with tightly coordinated epithelial and mesenchymal expression patterns for each time point and developmental stage. As such, it is reasonable to speculate that perturbation of WNT signaling on several levels during lung development may lead to the arrest of alveolarization and vascularization as observed clinically in BPD.

In contrast to mouse lung development, our knowledge about WNT signaling in human lung development remains sparse. To date, only two studies exist that reports on WNT signaling expression in developing human lung. Zhang et al. performed quantitative PCR and in situ hybridization using a developing human lung and showed that messenger RNA (mRNA) expression of WNT2, WNT7B, FZD4, FZD7, LRP5, and LRP6 was restricted to the alveolar and bronchial epithelium in the human lungs at 7, 12, 17, and 21 weeks of gestation [46]. Most WNT components were up-regulated gradually until 17 weeks and subsequently decreased in 21 weeks of gestation [46]. Sharma et al. performed differential gene expression analysis using human lung tissue samples across pseudoglandular and canalicular stages of development and DNA samples obtained from two cohorts of childhood bronchial asthma [47]. They showed that both WIF1 and Wnt1-inducible signaling pathway protein-1 (WISP1) are associated with intrauterine airway development and lung function impairment in childhood asthmatic patients [47].

Notably, there are several differences between mouse and human lung development in terms of cellular composition, timing of branching morphogenesis, or alveolar maturation [21, 48]. In the mouse lung, a pseudostratified epithelial layer including basal cells are only found in the trachea and main stem bronchus, whereas it is extended into terminal bronchioles in the human lung. In addition, club cells are found throughout mouse airways, while they are only found in the bronchiolar epithelium in the human lung. The number of the branches in the bronchial tree is higher in humans compared to mouse lungs. The lobation or branch pattern also differs between human and mouse [49]. Alveolar formation started from saccular stage, E17.5, in mouse, and around 24 weeks, late canalicular stage in human [48]. Considering these differences, further approaches to decipher the 
role of developmental signaling pathways in human lung development are required, using, e.g., human histological samples [50] or human induced pluripotent stem (iPS) cells [48].

\section{Involvement of WNT signaling in early lung injury and adult chronic lung diseases}

A number of environmental insults during pre- and postnatal development are known to induce deranged lung morphogenesis and have also been shown to affect WNT signaling. Several studies have been conducted to investigate whether insults to the developing lung by incidental environmental factors, such as postnatal infection or maternal cigarette smoke as well as medical interventions, such as ventilation and oxygen supplementation, affect lung morphogenesis and repair process via WNT signaling. Neonatal hyperoxia is one of the widely used animal (mainly rodent) models to mimic BPD, i.e., causing impaired alveolarization/vascularization in neonatal lungs [51]. Neonatal hyperoxia following maternal bacterial infection is another rodent model for BPD $[51,52]$. Since BPD is caused by a variety of factor, including hyperoxia exposure, intrauterine infection, highpressure ventilation, or prematurity of the lungs, rodent models of BPD, including hyperoxia exposure, do not completely recapitulate the BPD observed in clinical settings. However, because the lung samples from human neonates are rare, those rodent models of BPD, including hyperoxia exposure models focusing especially on alveolarization/vascularization, are important tools to reveal the pathophysiology of new BPD.

These pre- and postnatal insults can result in a variety of early lung diseases next to BPD. In particular, bronchial asthma exhibits a high incidence in childhood and adolescence. Bronchial asthma is considered to be highly influenced by maternal smoking [53], diet [54], intrauterine growth restriction [55, 56], or exposure to pathogens $[57,58]$. In this next section, we discuss the environmental insult-associated with altered $\mathrm{WNT} / \beta$-catenin signaling in lung injury occurring during early lung development and its potential contribution to adult chronic lung diseases.

\section{Infection and inflammation}

Prenatal infections are known to impact lung development. Premature rupture of the amniotic membrane results in increased susceptibility to intrauterine infections. Antenatal inflammation of chorioamniotic membranes causes premature birth and adversely affects lung development [59]. Intra-amniotic lipopolysaccharide (LPS) exposure, which mimics amniotic bacterial infection, decreases the expression of Lef-1, Wnt1, Wnt4, and $\beta$-catenin in the canalicular stage of lung development [60]. Similarly, in adult mice, acute lung injury caused by intra-tracheal application of LPS and followed by high tidal volume mechanical ventilation results in the activation of DKK1 and the subsequent down-regulation of active $\beta$-catenin in the lung alveolar epithelium. It was shown that DKK-1 is released from activated platelets, and the binding affinity of DKK-1 to alveolar epithelial cells was increased during acute lung inflammation [61]. Although only a few reports have shown the relationship between early lung infection/ inflammation and WNT signaling so far, the data to date are intriguing and further studies investigating human lungs undergoing prenatal infections, such as chorioamnionitis-induced neonatal lung injury, will be important.

\section{Smoking-related injury}

Maternal smoking is one of the important risk factors for chronic lung diseases in children including recurrent respiratory infection, infantile wheezing, bronchial asthma, and lower respiratory function in early adulthood [53, 62, 63]. It has also been shown that maternal smoking affects alveolarization/vascularization in developing lung in vivo [64, 65]. Bronchial asthma shares some similarities with BPD (e.g., pathologic airways and the presence of clinical symptoms like wheezing) and has been associated with aberrant WNT signaling as well $[47,66]$. Impaired lung growth by these and other environmental factors may cause the formation of smaller airways and decreased lung capacity contributing to childhood asthma and lower respiratory function in early adulthood [67]. In the adult lung, dysfunction of WNT signaling contributes to the impaired epithelial repair processes in disease $[17,68]$. WNT signaling is reduced in the lungs from COPD patients, a smoking-related disease, and the pharmacological activation of the signaling pathway through GSK3 $\beta$ inhibition activates epithelial repair properties and attenuates known pathological features of emphysema ex vivo [68] and in vivo [17, 69]. Recently, Jiang et al. reported that FAM13A, a gene associated with COPD susceptibility [69], might lead to emphysema development by facilitating $\beta$-catenin degradation [70]. Furthermore, WNT/ $\beta$-catenin signaling components, including canonical WNT ligands, FZDs, signal transducers, and target genes are down-regulated, while antagonists such as SFRP-1 and DKK-1 are upregulated, in human lung tissue [43] and in particular in the small airway epithelium [71, 72] from COPD patients.

Much less is known about the effects of maternal smoking on WNT signaling during lung development. Maternal smoking during pregnancy has been shown to decrease $F z d 7$ and Ctnnb1 ( $\beta$-catenin) mRNA in neonatal Balb/c mice [73]. Furthermore, it was recently reported that protein and mRNA expression of SFRP-1 were significantly up-regulated in the placental tissues in 
smoking women compared with those from nonsmokers [74]. Furthermore, a carbon monoxide analog, one of the components in cigarettes, increased SFRP-1 expression accompanied by decreased $\mathrm{WNT} / \beta$-catenin signaling in a human trophoblast cell line. In addition, maternal Sfrp-1 overexpression causes fetal growth restriction in mice [74]. Altogether, these studies strongly suggest that (maternal) smoking and components of cigarette smoke significantly impact WNT signaling activity. However, cigarette smoking is also known to generally inhibit fetal growth and thus it remains an open question whether maternal smoking/nicotine exposure directly increases extracellular modulators of WNT and decreases WNT/ $\beta$-catenin signaling in the lung to affect fetal lung development or whether maternal smoking/ nicotine exposure induces fetal growth restriction to cause premature birth and subsequent BPD.

Given these studies, it is plausible that chronic lung diseases, such as COPD, develop as a result of early lung insults leading to aberrant $\mathrm{WNT} / \beta$-catenin signaling and thus lung repair capacity. A gradual decline in lung function in early adulthood might be due to aberrant $\mathrm{WNT} / \beta$-catenin signaling, which is retained over time, eventually resulting in adult chronic lung diseases. Generation of experimental models to follow this hypothesis and long-term follow-up studies of new BPD patients are needed. In particular, emerging evidences suggest that epigenetic alterations, i.e., modified gene expression via DNA methylation, histone modification, or microRNA, of WNT signaling represents an important area of investigation. Recently, it has been shown that cigarette smoke exposure epigenetically altered $\mathrm{WNT} / \beta$-catenin signaling in lung cancer cells by histone modification or microRNA expression [75-77]. In the developing lung, differential methylation of $\mathrm{WNT} / \beta$-catenin signal genes have been reported in neonatal and adult mouse lungs [78]. Although there is no study addressing epigenetic alterations of WNT signaling by cigarette smoke exposure in the developing lung, it is reported that psychological stress during pregnancy caused altered DNA methylation of non-canonical, WNT5a/Ca ${ }^{2+}$ pathway and postnatal wheeze of the affected children [66]. As such, further investigations on how environmental factors, including maternal smoking, alter WNT signaling by epigenetic modifications and thus affect lung development of the neonate will be important.

\section{WNT/ $\beta$-catenin and TGF- $\beta$ signaling in new BPD}

In addition to $\mathrm{WNT} / \beta$-catenin, transforming growth factor (TGF)- $\beta$ signaling is a critical pathway for lung development [21]. It has been shown that TGF- $\beta$ is an important mediator for the development of BPD [79-81] and is activated in neonatal rat lungs after hyperoxia exposure [82] as well as in neonatal mouse lungs after mechanical ventilation with mild hyperoxia [83]. There are also reports regarding the dual activation of WNT/ $\beta$-catenin and TGF- $\beta$ signaling in hyperoxia exposure models, but the crosstalk between the two pathways is incompletely understood [82, 84]. Active WNT/B-catenin signaling has been reported in fibrotic adult lung diseases, such as IPF [14-16], in which TGF- $\beta$ signaling is highly involved in epithelial cell reprogramming and myofibroblast activation [85]. Furthermore, TGF- $\beta$ results in enhanced expression of WNT ligands and activation of $\beta$-catenin in vitro [86]. TGF- $\beta$-induced activation of $\mathrm{WNT} / \beta$-catenin signaling $[87,88]$ may also play a key role during developing BPD as well as adult fibrotic lung diseases, including IPF.

\section{WNT signaling in BPD}

To date, only a few studies addressed WNT signaling in new BPD patients. In the lungs of patients who died from BPD, nuclear $\beta$-catenin, which is used as a surrogate marker for $\mathrm{WNT} / \beta$-catenin activity, along with phosphorylated (inactivated) GSK-3 $\beta$ was found in the thickened alveolar septa $[89,90]$. Notably, whole exome sequencing using blood spots from twin neonate pairs with and without BPD revealed that genes associated with $\mathrm{WNT} / \beta$-catenin signaling were up-regulated in BPD [91].

Nuclear translocation of $\beta$-catenin and increased Lef1 expression was observed in the lung from neonatal rats exposed to hyperoxia ( $95 \%$ oxygen) in the alveolar stage (postnatal days 0 to 7) [82]. Moreover, it has been shown that neonatal hyperoxia increased nuclear $\beta$-catenin and decreased alveolar epithelial type II (ATII) cell to ATI cell transdifferentiation [84, 92], which is generally considered as a repair process of alveolar epithelial cells following injury. Furthermore, hyperoxia-induced inhibition of ATII to ATI transdifferentiation was recovered by small interfering RNA (siRNA)-mediated knockdown of Wnt3a in vitro [92]. However, it has been reported that in the adult mouse lung, $\beta$-catenin was induced during ATII cell to ATI cell transdifferentiation in normoxia condition $[93,94]$. This discrepancy might be due to hyperoxia condition or using neonatal lung in the former studies. Further studies are needed to clarify this issue. Another study showed the enhancement of WNT/ $\beta$-catenin signaling in impaired vascularization [95]. Taken together, canonical WNT/ $\beta$-catenin signaling is activated in lung samples from BPD patients and neonatal rodent model of hyperoxia exposure in the lung. This activation of WNT signaling might be a result of "attempted (and failed)" regeneration after injury of alveolar epithelial cells, which is a hypothesized processes model in IPF lungs [11].

It is unclear whether BPD contributes to the onset of adult chronic lung diseases, such as COPD or IPF. In 
adult chronic lung diseases, canonical $\mathrm{WNT} / \beta$-catenin signaling is down-regulated in emphysematous lungs [17] while up-regulated in fibrotic lungs [15]. In BPD lungs, as mentioned above, enhanced expression of TGF- $\beta$ [79] and/or WNT/ $\beta$-catenin signaling was observed $[89,90]$. In contrast, intrauterine infection or cigarette smoke decreased WNT/ $\beta$-catenin signaling. Longitudinal studies showed that along with decreased FEV1, a hallmark of obstructive lung diseases, forced vital capacity (FVC), a hallmark of restrictive lung diseases, was also lower in BPD survivors [96, 97]. Although characterizing a disease entity as either emphysema or fibrosis is oversimplification, it seems like BPD features a co-existence of emphysema and fibrosis as reported $[98,99]$. It is possible that different environmental insults at different time points during lung development might cause different expression patterns of WNT signaling. Also, if new BPD survivors with impaired alveolarization/vascularization are exposed to a "second hit," such as cigarette smoke, pathogens, or hyperoxia, at a later time point, they might develop adult chronic lung diseases with aberrant (increased/decreased) WNT signaling. Longitudinal studies are needed to study whether BPD survivors are more susceptible to developing adult chronic lung diseases. Establishing animal models to mimic BPD and follow the outcome of the developing lung is needed.

\section{Clinical implications and limitations of WNT/ $\beta$-catenin signaling in lung development}

Several studies indicated that targeting $\mathrm{WNT} / \beta$-catenin signaling may be a therapeutic strategy in BPD. Vitamin $\mathrm{A}$, whose metabolite is RA, has been used to prevent BPD progression [100-102] although the effect is still controversial. As mentioned previously, RA activated $\mathrm{WNT} / \beta$-catenin signaling via inhibition of DKK-1 [42]. In this context, active $\mathrm{WNT} / \beta$-catenin signaling might be beneficial for arrested alveolarization, as it has been reported to maintain alveolar stem/progenitor cell populations [11, 103], such as ATII cells [94].

On the other hand, it is reported that intraperitoneal administration of Mesd, a specialized chaperone for LRP5/6 to inhibit WNT/ $\beta$-catenin signaling, attenuated hyperoxia-induced pulmonary hypertension and right ventricular hypertrophy in neonatal rats [95]. Another study showed that ICG-001, a small molecule which inhibits WNT/ $\beta$-catenin signaling via interaction between $\beta$-catenin and CREB-binding protein (CBP), an intrinsic histone acetyltransferase to activate gene transcription, increased alveolarization and decreased vascular remodeling to develop pulmonary hypertension [104]. Resveratrol, a polyphenol found in several fruits and nuts, was also shown to attenuate hyperoxia-induced model of BPD in neonatal rats $[64,84]$. It is important to address the question when or where $\mathrm{WNT} / \beta$-catenin signaling should be inactivated/activated for physiologic lung development and perinatal lung injury/repair processes. Thus, it is worth exploring whether the attenuation of alveolar repair process or epigenetic modification altering WNT signaling will be candidates for clinical implications.

However, as most of the data shown here originate from rodent experiments, limitations for translation of the findings have to be considered. Given the difficulty of obtaining human neonatal lung tissue for analysis, recent approaches using 3D lung tissue cultures [68] or iPS cells $[105,106]$ from BPD patients represent promising tools to further explore signaling pathways involved in the pathogenesis of disease, such as $\mathrm{WNT} / \beta$-catenin signaling. Collecting more evidence from preterm infants will be needed to identify new therapeutic targets in $\mathrm{WNT} / \beta$-catenin signaling pathway.

\section{Conclusions}

Here, we discussed the potential role of the developmental WNT signaling pathway as a potential missing link between early impairment of lung development and the outcome in the adult lung. First, WNT/ $\beta$-catenin signaling is essential for lung development in utero, which has been elegantly investigated using the advantage of several wild-type and transgenic animals. Second, growing data suggest that $\mathrm{WNT} / \beta$-catenin signaling is involved in pre- and postnatal lung injury and repair process; and third, several lines of evidence exists that highlight the impact of impaired $\mathrm{WNT} / \beta$-catenin signaling on the development of adult chronic lung diseases, which seems similar to lung injury-repair processes in the developing lung. Additional studies are needed to advance our current knowledge of the pathogenesis of perinatal lung diseases, such as BPD, to shed further light into signaling pathways involved that ultimately might lead to novel therapeutic options for lung injury-repair process or epigenetic modifications in WNT signaling.

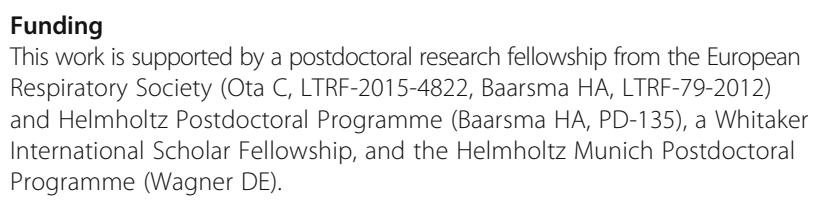
Respiratory Society (Ota C, LTRF-2015-4822, Baarsma HA, LTRF-79-2012) and Helmholtz Postdoctoral Programme (Baarsma HA, PD-135), a Whitaker International Scholar Fellowship, and the Helmholtz Munich Postdoctoral Programme (Wagner DE).

\section{Authors' contributions}

OC drafted the manuscript and contributed to the conception and the design and the acquisition of the data. BHA, WDE, HA, KM contributed to the acquisition of the data and revised the manuscript critically for important intellectual content. All authors read and approved the final manuscript.

\section{Competing interests}

The authors declare that they have no competing interests.

\section{Author details}

${ }^{1}$ Comprehensive Pneumology Center, Helmholtz Center Munich,

Ludwig-Maximilians-University, University Hospital Grosshadern, German 
Center of Lung Research (DZL), Munich, Germany. ${ }^{2}$ The Perinatal Center, Campus Grosshadern, Ludwig-Maximilians-University, Munich, Germany.

\section{Received: 10 March 2016 Accepted: 25 September 2016 Published online: 07 October 2016}

\section{References}

1. Northway WH Jr, Rosan RC, Porter DY (1967) Pulmonary disease following respirator therapy of hyaline-membrane disease. Bronchopulmonary dysplasia. N Engl J Med 276(7):357-368. doi:10.1056/NEJM196702162760701

2. Baraldi E, Filippone M (2007) Chronic lung disease after premature birth. N Engl J Med 357(19):1946-1955. doi:10.1056/NEJMra067279

3. Madurga A, Mizikova I, Ruiz-Camp J, Morty RE (2013) Recent advances in late lung development and the pathogenesis of bronchopulmonary dysplasia. American journal of physiology Lung cellular and molecular physiology 305(12):L893-L905. doi:10.1152/ajplung.00267.2013

4. Vollsaeter M, Roksund OD, Eide GE, Markestad T, Halvorsen T (2013) Lung function after preterm birth: development from mid-childhood to adulthood. Thorax 68(8):767-776. doi:10.1136/thoraxjnl-2012-202980

5. Ronkainen E, Dunder T, Peltoniemi O, Kaukola T, Marttila R, Hallman M (2015) New BPD predicts lung function at school age: follow-up study and meta-analysis. Pediatr Pulmonol 50(11):1090-1098. doi:10.1002/ppul.23153

6. Gibson AM, Reddington C, McBride L, Callanan C, Robertson C, Doyle LW (2015) Lung function in adult survivors of very low birth weight, with and without bronchopulmonary dysplasia. Pediatr Pulmonol 50(10):987-994. doi: 10.1002/ppul.23093

7. Stocks J, Hislop A, Sonnappa S (2013) Early lung development: lifelong effect on respiratory health and disease. Lancet Respir Med 1(9):728-742. doi:10.1016/S2213-2600(13)70118-8

8. Harding R, Maritz G (2012) Maternal and fetal origins of lung disease in adulthood. Seminars in fetal \& neonatal medicine 17(2):67-72. doi:10.1016/j. siny.2012.01.005

9. Kranenburg AR, De Boer WI, Van Krieken JH, Mooi WJ, Walters JE, Saxena PR, Sterk PJ, Sharma HS (2002) Enhanced expression of fibroblast growth factors and receptor FGFR-1 during vascular remodeling in chronic obstructive pulmonary disease. Am J Respir Cell Mol Biol 27(5):517-525. doi:10.1165/ rcmb.4474

10. Morino S, Nakamura T, Toba T, Takahashi M, Kushibiki T, Tabata Y, Shimizu Y (2005) Fibroblast growth factor-2 induces recovery of pulmonary blood flow in canine emphysema models. Chest 128(2):920-926. doi:10.1378/chest.128.2.920

11. Konigshoff M, Eickelberg $O$ (2010) WNT signaling in lung disease: a failure or a regeneration signal? Am J Respir Cell Mol Biol 42(1):21-31. doi:10.1165/ rcmb.2008-0485TR

12. Myllarniemi M, Lindholm P, Ryynanen MJ, Kliment CR, Salmenkivi K, KeskiOja J, Kinnula VL, Oury TD, Koli K (2008) Gremlin-mediated decrease in bone morphogenetic protein signaling promotes pulmonary fibrosis. Am J Respir Crit Care Med 177(3):321-329. doi:10.1164/rccm.200706-945OC

13. Beers MF, Morrisey EE (2011) The three R's of lung health and disease: repair, remodeling, and regeneration. J Clin Invest 121(6):2065-2073. doi:10.1172/JCl45961

14. Chilosi M, Poletti V, Zamo A, Lestani M, Montagna L, Piccoli P, Pedron S, Bertaso M, Scarpa A, Murer B, Cancellieri A, Maestro R, Semenzato G, Doglioni C (2003) Aberrant Wnt/beta-catenin pathway activation in idiopathic pulmonary fibrosis. Am J Pathol 162(5):1495-1502

15. Konigshoff M, Kramer M, Balsara N, Wilhelm J, Amarie OV, Jahn A, Rose F, Fink L, Seeger W, Schaefer L, Gunther A, Eickelberg O (2009) WNT1inducible signaling protein-1 mediates pulmonary fibrosis in mice and is upregulated in humans with idiopathic pulmonary fibrosis. J Clin Invest 119(4):772-787. doi:10.1172/JC133950

16. Konigshoff M, Balsara N, Pfaff EM, Kramer M, Chrobak I, Seeger W, Eickelberg O (2008) Functional Wnt signaling is increased in idiopathic pulmonary fibrosis. PLoS One 3(5):e2142. doi:10.1371/journal.pone.0002142

17. Kneidinger N, Yildirim AO, Callegari J, Takenaka S, Stein MM, Dumitrascu R, Bohla A, Bracke KR, Morty RE, Brusselle GG, Schermuly RT, Eickelberg O, Konigshoff M (2011) Activation of the WNT/beta-catenin pathway attenuates experimental emphysema. Am J Respir Crit Care Med 183(6): 723-733. doi:10.1164/rccm.200910-15600C

18. Krauss-Etschmann S, Bush A, Bellusci S, Brusselle GG, Dahlen SE, Dehmel S, Eickelberg O, Gibson G, Hylkema MN, Knaus P, Konigshoff M, Lloyd CM, Macciarini P, Mailleux A, Marsland BJ, Postma DS, Roberts G, Samakovlis C, Stocks J, Vandesompele J, Wjst M, Holloway J (2013) Of flies, mice and men: a systematic approach to understanding the early life origins of chronic lung disease. Thorax 68(4):380-384. doi:10.1136/thoraxjnl-2012-201902

19. Baarsma HA, Konigshoff M, Gosens R (2013) The WNT signaling pathway from ligand secretion to gene transcription: molecular mechanisms and pharmacological targets. Pharmacol Ther 138(1):66-83. doi:10.1016/j. pharmthera.2013.01.002

20. Volckaert T, De Langhe SP (2015) Wnt and FGF mediated epithelialmesenchymal crosstalk during lung development. Dev Dyn 244(3):342-366. doi:10.1002/dvdy.24234

21. Morrisey EE, Hogan BL (2010) Preparing for the first breath: genetic and cellular mechanisms in lung development. Dev Cell 18(1):8-23. doi:10.1016/j. devcel.2009.12.010

22. Tebar M, Destree O, de Vree WJ, Ten Have-Opbroek AA (2001) Expression of Tcf/Lef and sFrp and localization of beta-catenin in the developing mouse lung. Mech Dev 109(2):437-440

23. De Langhe SP, Carraro G, Tefft D, Li C, Xu X, Chai Y, Minoo P, Hajihosseini MK, Drouin J, Kaartinen V, Bellusci S (2008) Formation and differentiation of multiple mesenchymal lineages during lung development is regulated by beta-catenin signaling. PLoS One 3(1):e1516. doi:10.1371/journal.pone.0001516

24. Al Alam D, Green M, Tabatabai Irani R, Parsa S, Danopoulos S, Sala FG, Branch J, El Agha E, Tiozzo C, Voswinckel R, Jesudason EC, Warburton D, Bellusci S (2011) Contrasting expression of canonical Wnt signaling reporters TOPGAL, BATGAL and Axin2(LacZ) during murine lung development and repair. PLoS One 6(8): e23139. doi:10.1371/journal.pone.0023139

25. van Amerongen R, Berns A (2006) Knockout mouse models to study Wnt signal transduction. Trends Genet 22(12):678-689. doi:10.1016/j.tig.2006.10.001

26. Okubo T, Hogan BL (2004) Hyperactive Wnt signaling changes the developmental potential of embryonic lung endoderm. J Biol 3(3):11. doi:10.1186/jbiol3

27. Goss AM, Tian Y, Tsukiyama T, Cohen ED, Zhou D, Lu MM, Yamaguchi TP, Morrisey EE (2009) Wnt2/2b and beta-catenin signaling are necessary and sufficient to specify lung progenitors in the foregut. Dev Cell 17(2):290-298. doi:10.1016/j.devcel.2009.06.005

28. Mucenski ML, Wert SE, Nation JM, Loudy DE, Huelsken J, Birchmeier W, Morrisey EE, Whitsett JA (2003) beta-Catenin is required for specification of proximal/distal cell fate during lung morphogenesis. J Biol Chem 278(41): 40231-40238. doi:10.1074/jbc.M305892200

29. Rajagopal J, Carroll TJ, Guseh JS, Bores SA, Blank LJ, Anderson WJ, Yu J, Zhou Q, McMahon AP, Melton DA (2008) Wnt7b stimulates embryonic lung growth by coordinately increasing the replication of epithelium and mesenchyme. Development 135(9):1625-1634. doi:10.1242/dev.015495

30. Caprioli A, Villasenor A, Wylie LA, Braitsch C, Marty-Santos L, Barry D, Karner CM, Fu S, Meadows SM, Carroll TJ, Cleaver O (2015) Wnt4 is essential to normal mammalian lung development. Dev Biol 406(2):222-234. doi:10. 1016/j.ydbio.2015.08.017

31. Li C, Xiao J, Hormi K, Borok Z, Minoo P (2002) Wnt5a participates in distal lung morphogenesis. Dev Biol 248(1):68-81

32. Li C, Hu L, Xiao J, Chen H, Li JT, Bellusci S, Delanghe S, Minoo P (2005) Wnt5a regulates Shh and Fgf10 signaling during lung development. Dev Biol 287(1):86-97. doi:10.1016/j.ydbio.2005.08.035

33. Wang Z, Shu W, Lu MM, Morrisey EE (2005) Wnt7b activates canonical signaling in epithelial and vascular smooth muscle cells through interactions with Fzd1, Fzd10, and LRP5. Mol Cell Biol 25(12):5022-5030. doi: 10.1128/MCB.25.12.5022-5030.2005

34. Zhang Y, Goss AM, Cohen ED, Kadzik R, Lepore JJ, Muthukumaraswamy K, Yang J, DeMayo FJ, Whitsett JA, Parmacek MS, Morrisey EE (2008) A Gata6Wnt pathway required for epithelial stem cell development and airway regeneration. Nat Genet 40(7):862-870. doi:10.1038/ng.157

35. Kadzik RS, Cohen ED, Morley MP, Stewart KM, Lu MM, Morrisey EE (2014) Wnt ligand/Frizzled 2 receptor signaling regulates tube shape and branchpoint formation in the lung through control of epithelial cell shape. Proc Natl Acad Sci U S A 111(34):12444-12449. doi:10.1073/pnas.1406639111

36. De Langhe SP, Sala FG, Del Moral PM, Fairbanks TJ, Yamada KM, Warburton D, Burns RC, Bellusci S (2005) Dickkopf-1 (DKK1) reveals that fibronectin is a major target of Wnt signaling in branching morphogenesis of the mouse embryonic lung. Dev Biol 277(2):316-331. doi:10.1016/j.ydbio.2004.09.023

37. Mammoto $T$, Chen J, Jiang $E$, Jiang A, Smith LE, Ingber DE, Mammoto A (2012) LRP5 regulates development of lung microvessels and alveoli through the angiopoietin-Tie2 pathway. PLoS One 7(7):e41596. doi:10.1371/ journal.pone.0041596 
38. Harris-Johnson KS, Domyan ET, Vezina CM, Sun X (2009) beta-Catenin promotes respiratory progenitor identity in mouse foregut. Proc Natl Acad Sci U S A 106(38):16287-16292. doi:10.1073/pnas.0902274106

39. Hashimoto S, Chen H, Que J, Brockway BL, Drake JA, Snyder JC, Randell SH, Stripp BR (2012) beta-Catenin-SOX2 signaling regulates the fate of developing airway epithelium. J Cell Sci 125(Pt 4):932-942. doi:10.1242/jcs.092734

40. Cohen ED, Wang Z, Lepore JJ, Lu MM, Taketo MM, Epstein DJ, Morrisey EE (2007) Wnt/beta-catenin signaling promotes expansion of |s|-1-positive cardiac progenitor cells through regulation of FGF signaling. J Clin Invest 117(7):1794-1804. doi:10.1172/JCI31731

41. Shu W, Guttentag S, Wang Z, Andl T, Ballard P, Lu MM, Piccolo S, Birchmeier W, Whitsett JA, Millar SE, Morrisey EE (2005) Wnt/betacatenin signaling acts upstream of $\mathrm{N}$-myc, BMP4, and FGF signaling to regulate proximal-distal patterning in the lung. Dev Biol 283(1): 226-239. doi:10.1016/j.ydbio.2005.04.014

42. Chen F, Cao Y, Qian J, Shao F, Niederreither K, Cardoso WV (2010) A retinoic acid-dependent network in the foregut controls formation of the mouse lung primordium. J Clin Invest 120(6):2040-2048. doi:10.1172/JC140253

43. Foronjy R, Imai K, Shiomi T, Mercer B, Sklepkiewicz P, Thankachen J, Bodine P, D'Armiento J (2010) The divergent roles of secreted frizzled related protein-1 (SFRP1) in lung morphogenesis and emphysema. Am J Pathol 177(2):598-607. doi:10.2353/ajpath.2010.090803

44. Li A, Xing Y, Chan B, Heisterkamp N, Groffen J, Borok Z, Minoo P, Li C (2010) Cell type-specific expression of adenomatous polyposis coli in lung development, injury, and repair. Dev Dyn 239(8):2288-2297. doi:10.1002/dvdy.22364

45. Luo Y, El Agha E, Turcatel G, Chen H, Chiu J, Warburton D, Bellusci S, Qian BP, Menke DB, Shi W (2015) Mesenchymal adenomatous polyposis coli plays critical and diverse roles in regulating lung development. BMC Biol 13: 42. doi:10.1186/s12915-015-0153-1

46. Zhang M, Shi J, Huang Y, Lai L (2012) Expression of canonical WNT/betaCATENIN signaling components in the developing human lung. BMC Dev Biol 12:21. doi:10.1186/1471-213X-12-21

47. Sharma S, Tantisira K, Carey V, Murphy AJ, Lasky-Su J, Celedon JC, Lazarus R, Klanderman B, Rogers A, Soto-Quiros M, Avila L, Mariani T, Gaedigk R, Leeder S, Torday J, Warburton D, Raby B, Weiss ST (2010) A role for Wnt signaling genes in the pathogenesis of impaired lung function in asthma. Am J Respir Crit Care Med 181(4):328-336. doi:10.1164/rccm.200907-10090C

48. Snoeck HW (2015) Modeling human lung development and disease using pluripotent stem cells. Development 142(1):13-16. doi:10.1242/dev.115469

49. Metzger RJ, Klein OD, Martin GR, Krasnow MA (2008) The branching programme of mouse lung development. Nature 453(7196):745-750. doi:10.1038/nature07005

50. Suzuki T, Suzuki S, Fujino N, Ota C, Yamada M, Suzuki T, Yamaya M, Kondo T, Kubo H (2014) c-Kit immunoexpression delineates a putative endothelial progenitor cell population in developing human lungs. American journal of physiology Lung cellular and molecular physiology 306(9):L855-L865. doi:10. 1152/ajplung.00211.2013

51. Berger J, Bhandari V (2014) Animal models of bronchopulmonary dysplasia. The term mouse models. American journal of physiology Lung cellular and molecular physiology 307(12):L936-L947. doi:10.1152/ajplung.00159.2014

52. Velten M, Heyob KM, Rogers LK, Welty SE (2010) Deficits in lung alveolarization and function after systemic maternal inflammation and neonatal hyperoxia exposure. J Appl Physiol 108(5):1347-1356. doi:10.1152/ japplphysiol.01392.2009

53. den Dekker HT, Sonnenschein-van der Voort AM, de Jongste JC, Reiss IK, Hofman A, Jaddoe WW, Duijts L (2015) Tobacco smoke exposure, airway resistance, and asthma in school-age children: the generation $\mathrm{R}$ study. Chest 148(3):607-617. doi:10.1378/chest.14-1520

54. Thorburn AN, McKenzie Cl, Shen S, Stanley D, Macia L, Mason LJ, Roberts LK, Wong CH, Shim R, Robert R, Chevalier N, Tan JK, Marino E, Moore RJ, Wong L, McConville MJ, Tull DL, Wood LG, Murphy VE, Mattes J, Gibson PG, Mackay CR (2015) Evidence that asthma is a developmental origin disease influenced by maternal diet and bacterial metabolites. Nat Commun 6:7320. doi:10.1038/ncomms8320

55. Tedner SG, Ortqvist AK, Almqvist C (2012) Fetal growth and risk of childhood asthma and allergic disease. Clinical and experimental allergy: journal of the British Society for Allergy and Clinical Immunology 42(10): 1430-1447. doi:10.1111/j.1365-2222.2012.03997.x

56. Mu M, Ye S, Bai MJ, Liu GL, Tong Y, Wang SF, Sheng J (2014) Birth weight and subsequent risk of asthma: a systematic review and meta-analysis. Heart, lung \& circulation 23(6):511-519. doi:10.1016/j.hlc.2013.11.018
57. Duijts $L$ (2012) Fetal and infant origins of asthma. Eur J Epidemiol 27(1):5-14. doi:10.1007/s10654-012-9657-y

58. Beasley R, Semprini A, Mitchell EA (2015) Risk factors for asthma: is prevention possible? Lancet 386(9998):1075-1085. doi:10.1016/S01406736(15)00156-7

59. Goldenberg RL, Hauth JC, Andrews WW (2000) Intrauterine infection and preterm delivery. N Engl J Med 342(20):1500-1507. doi:10.1056/ NEJM200005183422007

60. Kuypers E, Willems MG, Collins JJ, Wolfs TG, Nitsos I, Jane Pillow J, Polglase GR, Kemp MW, Newnham JP, Delhaas T, Jobe AH, Kallapur SG, Kramer BW (2014) Altered canonical Wingless-Int signaling in the ovine fetal lung after exposure to intra-amniotic lipopolysaccharide and antenatal betamethasone. Pediatr Res 75(2):281-287. doi:10.1038/pr.2013.226

61. Guo Y, Mishra A, Howland E, Zhao C, Shukla D, Weng T, Liu L (2015) Platelet-derived Wnt antagonist Dickkopf-1 is implicated in ICAM-1/NCAM-1mediated neutrophilic acute lung inflammation. Blood 126(19):2220-2229. doi:10.1182/blood-2015-02-622233

62. Strachan DP, Cook DG (1998) Health effects of passive smoking. 6. Parental smoking and childhood asthma: Iongitudinal and case-control studies. Thorax 53(3):204-212

63. Svanes C, Sunyer J, Plana E, Dharmage S, Heinrich J, Jarvis D, de Marco R, Norback D, Raherison C, Villani S, Wjst M, Svanes K, Anto JM (2010) Early life origins of chronic obstructive pulmonary disease. Thorax 65(1):14-20. doi:10. 1136/thx.2008.112136

64. Ozdemir OM, Gozkeser E, Bir F, Yenisey C (2014) The effects of resveratrol on hyperoxia-induced lung injury in neonatal rats. Pediatrics and neonatology 55(5):352-357. doi:10.1016/j.pedneo.2013.11.004

65. Manoli SE, Smith LA, Vyhlidal CA, An CH, Porrata Y, Cardoso WV, Baron RM, Haley KJ (2012) Maternal smoking and the retinoid pathway in the developing lung. Respir Res 13:42. doi:10.1186/1465-9921-13-42

66. Trump S, Bieg M, Gu Z, Thurmann L, Bauer T, Bauer M, Ishaque N, Roder S, Gu L, Herberth G, Lawerenz C, Borte M, Schlesner M, Plass C, Diessl N, Eszlinger M, Mucke O, Elvers HD, Wissenbach DK, von Bergen M, Herrmann C, Weichenhan D, Wright RJ, Lehmann I, Eils R (2016) Prenatal maternal stress and wheeze in children: novel insights into epigenetic regulation. Scientific reports 6:28616. doi:10.1038/srep28616

67. Canoy D, Pekkanen J, Elliott P, Pouta A, Laitinen J, Hartikainen AL, Zitting P, Patel S, Little MP, Jarvelin MR (2007) Early growth and adult respiratory function in men and women followed from the fetal period to adulthood. Thorax 62(5):396-402. doi:10.1136/thx.2006.066241

68. Uhl FE, Vierkotten S, Wagner DE, Burgstaller G, Costa R, Koch I, Lindner M, Meiners S, Eickelberg O, Konigshoff M (2015) Preclinical validation and imaging of Wnt-induced repair in human 3D lung tissue cultures. Eur Respir J 46(4):1150-1166. doi:10.1183/09031936.00183214

69. Wang B, Liang B, Yang J, Xiao J, Ma C, Xu S, Lei J, Xu X, Liao Z, Liu H, Ou X, Feng $Y$ (2013) Association of FAM13A polymorphisms with COPD and COPD-related phenotypes in Han Chinese. Clin Biochem 46(16-17):16831688. doi:10.1016/j.clinbiochem.2013.07.013

70. Jiang Z, Lao T, Qiu W, Polverino F, Gupta K, Guo F, Mancini JD, Naing ZZ, Cho MH, Castaldi PJ, Sun Y, Yu J, Laucho-Contreras ME, Kobzik L, Raby BA, Choi AM, Perrella MA, Owen CA, Silverman EK, Zhou X (2016) A chronic obstructive pulmonary disease susceptibility gene, FAM13A, regulates protein stability of beta-catenin. Am J Respir Crit Care Med. doi: 10.1164/ rccm.201505-09990C

71. Heijink $\mathbb{H}$, de Bruin $H G$, van den Berge $M$, Bennink $\sqcup$, Brandenburg SM, Gosens $R$, van Oosterhout AJ, Postma DS (2013) Role of aberrant WNT signalling in the airway epithelial response to cigarette smoke in chronic obstructive pulmonary disease. Thorax 68(8):709-716. doi:10.1136/thoraxjnl-2012-201667

72. Wang R, Ahmed J, Wang G, Hassan I, Strulovici-Barel Y, Hackett NR, Crystal RG (2011) Down-regulation of the canonical Wnt beta-catenin pathway in the airway epithelium of healthy smokers and smokers with COPD. PLOS One 6(4):e14793. doi:10.1371/journal.pone.0014793

73. Blacquiere MJ, Timens W, van den Berg A, Geerlings M, Postma DS, Hylkema MN (2010) Maternal smoking during pregnancy decreases Wnt signalling in neonatal mice. Thorax 65(6):553-554. doi:10.1136/thx.2009.120154

74. Wang A, Zsengeller ZK, Hecht JL, Buccafusca R, Burke SD, Rajakumar A, Weingart E, Yu PB, Salahuddin S, Karumanchi SA (2015) Excess placental secreted frizzled-related protein 1 in maternal smokers impairs fetal growth. J Clin Invest 125(11):4021-4025. doi:10.1172/JCl80457

75. Hussain M, Rao M, Humphries AE, Hong JA, Liu F, Yang M, Caragacianu D, Schrump DS (2009) Tobacco smoke induces polycomb-mediated repression 
of Dickkopf-1 in lung cancer cells. Cancer Res 69(8):3570-3578. doi:10.1158/ 0008-5472.CAN-08-2807

76. Liu F, Killian JK, Yang M, Walker RL, Hong JA, Zhang M, Davis S, Zhang Y, Hussain M, Xi S, Rao M, Meltzer PA, Schrump DS (2010) Epigenomic alterations and gene expression profiles in respiratory epithelia exposed to cigarette smoke condensate. Oncogene 29(25):3650-3664. doi:10.1038/onc.2010.129

77. Xi S, Xu H, Shan J, Tao Y, Hong JA, Inchauste S, Zhang M, Kunst TF, Mercedes L, Schrump DS (2013) Cigarette smoke mediates epigenetic repression of miR-487b during pulmonary carcinogenesis. J Clin Invest 123(3):1241-1261. doi:10.1172/JCI61271

78. Cuna A, Halloran B, Faye-Petersen O, Kelly D, Crossman DK, Cui X, Pandit K, Kaminski N, Bhattacharya S, Ahmad A, Mariani TJ, Ambalavanan N (2015) Alterations in gene expression and DNA methylation during murine and human lung alveolar septation. Am J Respir Cell Mol Biol 53(1):60-73. doi:10. 1165/rcmb.2014-01600C

79. Gauldie J, Galt T, Bonniaud P, Robbins C, Kelly M, Warburton D (2003) Transfer of the active form of transforming growth factor-beta 1 gene to newborn rat lung induces changes consistent with bronchopulmonary dysplasia. Am J Pathol 163(6):2575-2584

80. Ahlfeld SK, Wang J, Gao Y, Snider P, Conway SJ (2016) Initial suppression of transforming growth factor-beta signaling and loss of TGFBI causes early alveolar structural defects resulting in bronchopulmonary dysplasia. Am J Pathol 186(4):777-793. doi:10.1016/j.ajpath.2015.11.024

81. Morty RE, Konigshoff M, Eickelberg O (2009) Transforming growth factorbeta signaling across ages: from distorted lung development to chronic obstructive pulmonary disease. Proc Am Thorac Soc 6(7):607-613. doi:10 1513/pats.200908-087RM

82. Dasgupta C, Sakurai R, Wang Y, Guo P, Ambalavanan N, Torday JS, Rehan VK (2009) Hyperoxia-induced neonatal rat lung injury involves activation of TGF-\{beta\} and Wnt signaling and is protected by rosiglitazone. American journal of physiology Lung cellular and molecular physiology 296(6):L1031L1041. doi:10.1152/ajplung.90392.2008

83. Hilgendorff A, Parai K, Ertsey R, Jain N, Navarro EF, Peterson JL, Tamosiuniene R, Nicolls MR, Starcher BC, Rabinovitch M, Bland RD (2011) Inhibiting lung elastase activity enables lung growth in mechanically ventilated newborn mice. Am J Respir Crit Care Med 184(5):537-546. doi:10. 1164/rccm.201012-20100C

84. Xu W, Zhao Y, Zhang B, Xu B, Yang Y, Wang Y, Liu C (2015) Resveratrol attenuates hyperoxia-induced oxidative stress, inflammation and fibrosis and suppresses Wnt/beta-catenin signalling in lungs of neonatal rats. Clin Exp Pharmacol Physiol 42(10):1075-1083. doi:10.1111/1440-1681.12459

85. Fernandez IE, Eickelberg O (2012) New cellular and molecular mechanisms of lung injury and fibrosis in idiopathic pulmonary fibrosis. Lancet 380(9842):680-688. doi:10.1016/50140-6736(12)61144-1

86. Baarsma HA, Engelbertink LH, van Hees LJ, Menzen MH, Meurs H, Timens W, Postma DS, Kerstjens HA, Gosens R (2013) Glycogen synthase kinase-3 (GSK3) regulates TGF-beta(1)-induced differentiation of pulmonary fibroblasts. $\mathrm{Br}$ J Pharmacol 169(3):590-603. doi:10.1111/bph.12098

87. Spanjer Al, Baarsma HA, Oostenbrink LM, Jansen SR, Kuipers CC, Lindner M, Postma DS, Meurs H, Heijink IH, Gosens R, Konigshoff M (2016) TGF-betainduced profibrotic signaling is regulated in part by the WNT receptor Frizzled-8. FASEB journal: official publication of the Federation of American Societies for Experimental Biology 30(5):1823-1835. doi:10.1096/fj.201500129

88. Zhou Q, Chen T, Bozkanat M, Ibe JC, Christman JW, Raj JU, Zhou G (2014) Intratracheal instillation of high dose adenoviral vectors is sufficient to induce lung injury and fibrosis in mice. PLoS One 9(12):e116142. doi:10, 1371/journal.pone.0116142

89. Popova AP, Bentley JK, Anyanwu AC, Richardson MN, Linn MJ, Lei J, Wong EJ, Goldsmith AM, Pryhuber GS, Hershenson MB (2012) Glycogen synthase kinase-3beta/beta-catenin signaling regulates neonatal lung mesenchymal stromal cell myofibroblastic differentiation. American journal of physiology Lung cellular and molecular physiology 303(5):L439-L448. doi:10.1152/ ajplung.00408.2011

90. Hummler SC, Rong M, Chen S, Hehre D, Alapati D, Wu S (2013) Targeting glycogen synthase kinase-3beta to prevent hyperoxia-induced lung injury in neonatal rats. Am J Respir Cell Mol Biol 48(5):578-588. doi:10.1165/rcmb. 2012-03830C

91. Li J, Yu KH, Oehlert J, Jeliffe-Pawlowski LL, Gould JB, Stevenson DK, Snyder M, Shaw GM, O'Brodovich HM (2015) Exome sequencing of neonatal blood spots and the identification of genes implicated in bronchopulmonary dysplasia. Am J Respir Crit Care Med 192(5):589-596. doi:10.1164/rccm. 201501-01680C

92. Xu W, Zhao Y, Zhang B, Xu B, Yang Y, Wang Y, Liu C (2015) Wnt3a mediates the inhibitory effect of hyperoxia on the transdifferentiation of AEClls to AECls. The journal of histochemistry and cytochemistry: official journal of the Histochemistry Society 63(11):879-891. doi:10.1369/0022155415600032

93. Flozak AS, Lam AP, Russell S, Jain M, Peled ON, Sheppard KA, Beri R, Mutlu GM, Budinger GR, Gottardi CJ (2010) Beta-catenin/T-cell factor signaling is activated during lung injury and promotes the survival and migration of alveolar epithelial cells. J Biol Chem 285(5):3157-3167. doi:10.1074/jbc.M109. 070326

94. Mutze K, Vierkotten S, Milosevic J, Eickelberg O, Konigshoff M (2015) Enolase 1 (ENO1) and protein disulfide-isomerase associated 3 (PDIA3) regulate Wnt/beta-catenin-driven trans-differentiation of murine alveolar epithelial cells. Disease models \& mechanisms 8(8):877-890. doi:10.1242/dmm.019117

95. Alapati D, Rong M, Chen S, Lin C, Li Y, Wu S (2013) Inhibition of LRP5/6mediated Wnt/beta-catenin signaling by Mesd attenuates hyperoxiainduced pulmonary hypertension in neonatal rats. Pediatr Res 73(6):719725. doi:10.1038/pr.2013.42

96. Filbrun AG, Popova AP, Linn MJ, McIntosh NA, Hershenson MB (2011) Longitudinal measures of lung function in infants with bronchopulmonary dysplasia. Pediatr Pulmonol 46(4):369-375. doi:10.1002/ppul.21378

97. Gough A, Linden M, Spence D, Patterson CC, Halliday HL, McGarvey LP (2014) Impaired lung function and health status in adult survivors of bronchopulmonary dysplasia. The European respiratory journal 43(3):808816. doi:10.1183/09031936.00039513

98. Tonson la Tour A, Spadola L, Sayegh Y, Combescure C, Pfister R, Argiroffo CB, Rochat I (2013) Chest CT in bronchopulmonary dysplasia: clinical and radiological correlations. Pediatr Pulmonol 48(7):693-698. doi:10.1002/ppul.22714

99. Walkup LL, Tkach JA, Higano NS, Thomen RP, Fain SB, Merhar SL, Fleck RJ, Amin RS, Woods JC (2015) Quantitative magnetic resonance imaging of bronchopulmonary dysplasia in the neonatal intensive care unit environment. Am J Respir Crit Care Med 192(10):1215-1222. doi:10.1164/ rccm.201503-05520C

100. Laughon MM (2014) Vitamin A shortage and risk of bronchopulmonary dysplasia. JAMA Pediatr 168(11):995-996. doi:10.1001/jamapediatrics.2014.1416

101. Hutten MC, Wolfs TG, Kramer BW (2016) Can the preterm lung recover from perinatal stress? Molecular and cellular pediatrics 3(1):15. doi:10.1186/ s40348-016-0043-9

102. Couroucli XI, Placencia JL, Cates LA, Suresh GK (2016) Should we still use vitamin A to prevent bronchopulmonary dysplasia? Journal of perinatology: official journal of the California Perinatal Association 36(8):581-585. doi:10. 1038/jp.2016.76

103. Crosby LM, Waters CM (2010) Epithelial repair mechanisms in the lung. American journal of physiology Lung cellular and molecular physiology 298(6):L715-L731. doi:10.1152/ajplung.00361.2009

104. Alapati D, Rong M, Chen S, Hehre D, Hummler SC, Wu S (2014) Inhibition of beta-catenin signaling improves alveolarization and reduces pulmonary hypertension in experimental bronchopulmonary dysplasia. Am J Respir Cell Mol Biol 51(1):104-113. doi:10.1165/rcmb.2013-03460C

105. Huang SX, Islam MN, O'Neill J, Hu Z, Yang YG, Chen YW, Mumau M, Green MD, Vunjak-Novakovic G, Bhattacharya J, Snoeck HW (2014) Efficient generation of lung and airway epithelial cells from human pluripotent stem cells. Nat Biotechnol 32(1):84-91. doi:10.1038/nbt.2754

106. Firth AL, Menon T, Parker GS, Qualls SJ, Lewis BM, Ke E, Dargitz CT, Wright R, Khanna A, Gage FH, Verma IM (2015) Functional gene correction for cystic fibrosis in lung epithelial cells generated from patient iPSCs. Cell Rep 12(9):1385-1390. doi:10.1016/j.celrep.2015.07.062 